\title{
Murine peripheral blood prognostic biomarkers for tumor survival following combination aCTLA-4 and aPD-1 treatment
}

Ian Hilgart-Martiszus ${ }^{1 *}$, Michael McNamara ${ }^{1,2}$, William Redmond ${ }^{1,2}$

From 30th Annual Meeting and Associated Programs of the Society for Immunotherapy of Cancer (SITC 2015) National Harbor, MD, USA. 4-8 November 2015

\section{Background}

Immune checkpoint inhibitors, particularly those targeting CTLA-4 and PD-1, are transforming the way cancer is treated. However, these therapies do not benefit all patients and frequently cause significant immune-related adverse events. Therefore, prognostic biomarkers that identify positively-responding patients, early in the course of therapy, are essential for guiding treatment decisions and improving patient outcomes.

\section{Methods}

In this study, we present evidence that shortly after initiating combination PD-1/CTLA-4 blockade, there is a transient increase in the frequency of pro-inflammatory and cytotoxic lymphocytes in peripheral blood, and the dynamics of this shift correlate with survival outcomes in multiple murine models.

\section{Results}

Specifically, we observed that 1) the relative frequency of cytotoxic CD8 T cells among peripheral lymphocytes and 2) the pro-inflammatory capacity of peripheral lymphocytes are both predictive for outcomes at an early time point. Surprisingly, robust correlations between peripheral lymphocyte markers and outcomes were limited to CD8 T cell populations. In general, the expression of potential biomarkers on peripheral CD4 T cells, including ICOS and FoxP3, were poorly correlated with outcomes in this study.

\section{Conclusions}

Overall, these findings suggest that elements of the near-term peripheral immune response to dual

${ }^{1}$ Earle A Chiles Research Institute, Portland, OR, USA

Full list of author information is available at the end of the article
anti-PD-1/anti-CTLA-4 therapy associated with cytotoxic lymphocyte function may provide unique prognostic biomarkers for therapeutic outcomes.

\section{Authors' details}

'Earle A Chiles Research Institute, Portland, OR, USA. ${ }^{2}$ Providence Cancer Center, Portland, OR, USA.

Published: 4 November 2015

doi:10.1186/2051-1426-3-S2-P91

Cite this article as: Hilgart-Martiszus et al: Murine peripheral blood prognostic biomarkers for tumor survival following combination aCTLA4 and aPD-1 treatment. Journal for ImmunoTherapy of Cancer 20153 (Suppl 2):P91.

\section{Submit your next manuscript to BioMed Central and take full advantage of: \\ - Convenient online submission \\ - Thorough peer review \\ - No space constraints or color figure charges \\ - Immediate publication on acceptance \\ - Inclusion in PubMed, CAS, Scopus and Google Scholar \\ - Research which is freely available for redistribution




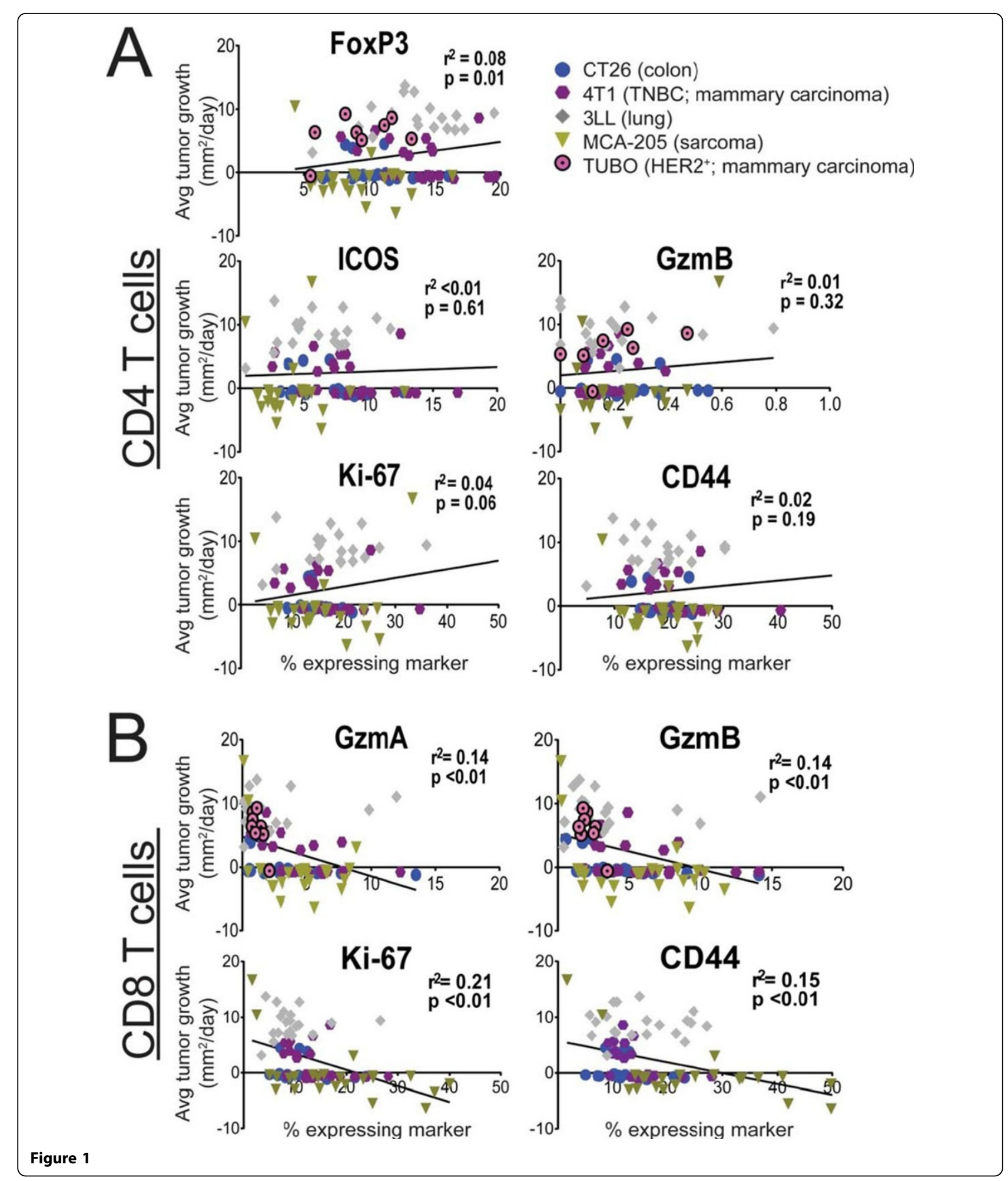

